\title{
Consensual Union in West Africa
}

\section{Ntoimo Lorretta Favour Chizomam ${ }^{1}$, Odimegwu Clifford ${ }^{2}$, Dansou Justin ${ }^{3}$, Ola Tolulope $\mathbf{M}^{4}$}

\author{
${ }^{1}$ Department of Demography and Social Statistics, Federal University Oye-Ekiti, Nigeria \\ ntoimo.lorretta@gmail.com
}

\begin{abstract}
${ }^{2}$ Demography and Population Studies Programme, University of the Witwatersrand, Johannesburg, South Africa
\end{abstract}

\author{
${ }^{3}$ Pan African University Institute of Life and Earth Sciences, \\ University of Ibadan, Nigeria \\ ${ }^{4}$ University of Minnesota, USA/Ekiti State University, Nigeria.
}

\begin{abstract}
One of the major changes in family formation is the increasing tendency for people to enter into coresident patterning without formalising the union through religious, civil or traditional rites. Despite the implications, this nuptiality behavior which is well documented in the more developed regions, has received negligible scholarly attention in Africa. Using three ranks of DHS surveys (1998-20I4) in twelve countries, this study examined the levels, trends, individual and contextual factors associated with consensual union in West Africa. Descriptive results showed a rising trend in consensual union in the sub-region. Multilevel logistic regression analysis suggests that individual-level factors associated with consensual union included education, spousal age gap, second and higher order union, premarital birth, age at first sex, number of sons among others. Contextual predictors were community poverty level, proportion of educated women and proportion of divorced and separated women. Given the health and welfare implications of consensual union, the findings underscore the need for policies and programmatic interventions to protect women in consensual unions, and to extend the benefits of formal marriage to consensual union in case of break up.
\end{abstract}

Key words: Consensual union; West Africa; Marriage; family formation; Women

\section{Introduction}

Globally, one of the major changes in family formation is the increasing tendency for people to enter into co-resident patterning without formalising the union through religious, civil or traditional rites (Jensen \& Clausen, 2003; Kennedy \& Bumpass, 2008; Lyngstad, 20l I). This tendency known as consensual union, common-law union or cohabitation, which is more prevalent in the developed countries, often as a prelude to formal marriage has been thought to be a feature of the second demographic transition as people are increasingly seeking personal freedom from institutionalisation of personal relationships, such as marital union (van de Kaa, 1987). In many developing countries, informal unions, such as consensual union has always existed alongside formal unions, but in recent decades it is increasingly becoming a common nuptiality feature of many developing nations. (Martin, 2002; Meekers, 1992). For instance, in Burkina Faso 5 to 10 percent of all unions in 1969 were consensual (LeGrand \& Younoussi, 2009). In Liberia, 30 percent of women aged I5-49 years were in consensual union in 2013, 23 percent in Cote d'lvoire in 2012 and 14.9 percent in Togo in 2014 (ICF International, 20I5).

Consensual union is consequential for women, men and children's welfare. Although couples in consensual union may benefit from the social, economic and health benefits associated with formal marriage, because consensual union lacks the legal and normative structure that specify rights, responsibilities and appropriate behaviour in a formalised union, couples in consensual union may be less advantaged in health and general well-being (Musick \& Bumpass, 2012; Osborne \& McLanahan, 2007) . For instance, Women and men in cohabiting union in Mexico reported higher depressive symptoms than their counterparts in marital union (Schmeer \& Kroeger, 20II). Further, consensual union may be an indication of less commitment to a marital union (Bracher, Santow, Morgan, \& Trussell, 1993), Thus, the man and woman may have other sexual partners, which increases the risk of 
separation and sexually transmitted infections. Low commitment by the man may also lead to inadequate maternal and child care, particularly in a region, such as West Africa where poverty is pervasive and highly feminised, sexual initiation and marriage for women is early, and women constitute the majority of the illiterate and unemployed population (UNDP, 20I4). A study in Honduras shows that women as well as men in consensual union were more likely to believe that husbands alone should make decisions on family size and use of family planning than those in formal union (Speizer, Whittle, \& Carter, 2005). This indicates that poor women in consensual union are more likely to be defenceless, insecure and exposed to risk of poor reproductive health than their married counterparts. Not having institutional approval exposes women and children in consensual union to being abandoned by partners who are not loyal, thus increasing their vulnerability. In case of dissolution through separation, which is more common in consensual union (Andersson, 2004; Jensen \& Clausen, 2003), or death, the partners may not benefit from the social and economic rights of persons in formalised unions (Martin, 2002). The prevalence of consensual union is also consequential for other demographic outcomes, such as fertility patterns (Hoem, Kostova, Jasilioniene, \& Mureşan, 2009; Laplante \& Fostik, 20I5).

Although relationships that start as consensual union in West Africa may be formalised, many couples stay long in consensual union (LeGrand \& Younoussi, 2009) before formalising their union. Thus, women, men and children are exposed over a long period to the disadvantages associated with the consensual union before the union is formalised. A study shows that irrespective of selection factors, premarital cohabitation increases the risk of poorer marital quality and greater instability (Dush, Cohan, \& Amato, 2003). Therefore, this study examined the levels, trends, individual and contextual factors associated with consensual union in West Africa. Compared to other sub-regions in sub-Saharan Africa, early marriage is more prevalent among women in West Africa. A scholarly investigation into the levels, trends and factors associated with consensual union in West Africa is important to highlight transformations in union formation in the sub-region, and their implications.

\section{Literature review}

The importance of individual characteristics in explaining demographic outcomes, such as union formation is well established in the literature and there is a growing research interest in the association between one's neighbourhood and individual-level behaviour. For instance, in Latin America, higher odds of consensual union were associated with lack of education, second or higher order union, young age at first union, premarital birth, sexual activity before union (Martin, 2002). Consensual union was also associated with educational attainment in Finland (Finnäs, 1995), and with re-partnering after bereavement or divorce in the Netherlands (De Jong Gierveld, 2004). According to some theoretical arguments, recurrence and variation of consensual union rates in Africa may be mainly accounted for by both culture and socio-economic factors (Locoh, 2002; Thiriat, 1999) because of persisting socioeconomic inequalities and cultural divergences despite the influence of religious precepts and the modern law after the colonization (Locoh, 2002; Antoine, 2007).

The majority of empirical studies in sub-Saharan Africa have highlighted the importance of these cultural and socioeconomic factors. Among them are the studies of Kamgno \& Mengue (2014) in Cameroun, LeGrand \& Younoussi (2009) in Burkina Faso, Thiriat (1999) in Togo, Arnaldo (2004) in Mozambique. In Burkina Faso, individual-level factors such as education, religion, ethnic origin, previous union experience were significantly associated with consensual union (LeGrand \& Younoussi, 2009). However, this study was only in Burkina Faso; and tested specific hypotheses on the influence of modern characteristics (education and urban residence), family disapproval of a union, unions that begun abroad, inter-ethnic union, and higher order union on the likelihood of forming consensual union by women and men. The current study extends by exploring more individual-level, and contextual factors associated with consensual union in West Africa.

In some Sub-Saharan countries, a big importance is given to dowry and bride wealth and it often precedes any formal union (Isiugo-Abanihe, 1994; Kalule-Sabiti, Palamuleni, Makiwane \& Amoateng, 2007). For instance, young Beti in Cameroon could not go into formal union without dowry (Kamdem, 2006). The influence of bride wealth and dowry was also shown in Mozambique (Arnaldo, 2004), Nigeria (Isiugo-Abanihe, 1994) and Burkina Faso (LeGrand \& Younoussi, 2009). Due to economic downturn and uncertainties in many countries in West Africa, it is increasingly more difficult for men to establish sustainable livelihood. With unstable economic status, men would either postpone marriage or enter into a less-committal union - consensual union (Kalmijn, 20II; Kamgno \& Mengue, 20I4). However, because kin support and extended family ties are still prevalent in many countries in West Africa, young men who wish to marry may be supported by their kinsmen in bride wealth payment and wedding 
ceremonies. Another factor that is usually associated with consensual union in African countries is childbirth (Adjamagbo, Antoine, Toudéka, Kpadonou, \& Fageac, 2014; Martin, 2002). Lack of live birth especially of a boy increases the likelihood that a union remains consensual (Adjamagbo et al., 20/4). A child is considered as a means for descendant perpetuation (Rwenge, 2002) and old age insurance for the parents (Diop, I98I; Ela, 1995).

There is a growing tendency among young generations to live in consensual unions, although this is well known to vary between and within countries (Adjamagbo et al., 20l4) as shown in Cameron among younger women (Kamgno \& Mengue, 2014) and Latin America (Martin, 2002). Consensual union in sub-Saharan Africa is also more prevalent in urban areas (Meekers, 1992; Thiriat, 1999; Kamgno \& Mengue, 20I4; LeGrand \& Younoussi, 2009), among well educated people, return migrants (Kamgno \& Mengue, 20I4; LeGrand \& Younoussi, 2009) and among non-cohabiting spouses (Adjamagbo et al., 2014). On the contrary, in Latin America, there was a mixed result with urban residents being more likely to be in consensual union in some countries and in others, rural residents (Martin, 2002). Other factor associated with consensual union in West Africa is elopement as described in (LeGrand \& Younoussi (2009) where a young couple who failed to get the consent of the woman's parents, elope to start a family life. Among the Igbo of Nigeria, if the marriage was forbidden on the ground of prohibition of crosscaste marriage, the union will remain consensual as the parents may never give their approval (Dike, 2002).

With regard to the influence of contextual factors, past studies show that neighbourhood context working through social and other mechanisms influence individual-level behaviour (Browning, Leventhal, \& Brooks-Gunn, 2005; Galster, 20I2). For instance, community-factors influence the risk of divorce (Lyngstad, 20II), sexual and reproductive health (Lindberg \& Orr, 20II; Ononokpono, Odimegwu, Imasiku, \& Adedini, 20I4), relationship formation and sexual initiation among adolescents (Browning et al., 2005; Raley \& Sullivan, 2009), female adolescent childbearing before marriage (South \& Baumer, 200I; South \& Crowder, 20I0), and many other individual-level behaviour. Communities are usually heterogeneous in economic, social and demographic contexts, thus, it is expected that prevalence and social acceptability of consensual union will vary across communities. For instance, a study in Canada showed that consensual union was more prevalent in the French speaking Quebec than in other parts of Canada (Laplante \& Fostik, 20I5). Similarly, some authors in sub-Saharan Africa pointed out the important role played by socio-economic environment in promoting consensual union in the region (Arnaldo, 2004; Kamgno \& Mengue, 2014; Locoh, 2002). It is likely that community-level factors (not only place of residence), such as the proportion of poor persons in a community, proportion of women who have attained secondary and tertiary education, and other factors will influence the prevalence of consensual union in West Africa.

\section{Methods \\ Data}

This study utilized data obtained from the last three Demographic and Health Surveys (DHS) in twelve West African countries, except in Sierra Leone where there was only two DHS, and Togo where the third most recent DHS was in 1988 and women in union were not disaggregated into married and living together. The countries and survey years were: Burkina Faso (1998-99, 2003 \& 20I0), Benin (200I, 2006 \& 20II-I2), Cote d'lvoire (I998-99, 2005 \& 20I I-I2), Ghana (2003, 2008 \& 20I4), Guinea (I999, 2005 \& 20I2), Liberia (I986, 2007 \& 2013 ), Mali (200I, 2006 \& 20I2-I3), Nigeria (2003, 2008 \& 20I3), Niger (1998, 2006 \& 20I2), Sierra Leone (2008 \& 20I3), Senegal (1997, 2005 \& 20I0-II) and Togo (1998 \& 2013-14). Using a nationally representative sample of women aged 15-49 years; the Measure DHS collects data on marriage, health and several individual and household characteristics. The primary sampling unit (PSU) also regarded as cluster in the DHS surveys were defined on the basis of Enumeration Areas provided by the national census bodies in the various countries. The community variables for this study were measured at the level of the PSU or cluster which served as proxy for community.

The study population comprised women in union (married and living together), aged 15-49 years. After pooling the datasets for the most recent surveys in the twelve countries, there was a weighted sample of 123,047 women who were married or living together. Normalised weighted frequencies for each country were: Burkina Faso $(13,563)$, Benin $(11,680)$, Cote d'Ivoire $(6,309)$, Ghana $(5,321)$, Guinea $(6,726)$, Liberia $(5,386)$, Mali $(8,820)$, Nigeria $(27,829)$, Niger $(9,881)$, Sierra Leone $(10,903)$, Senegal $(10,347)$ and Togo $(6,282)$

\section{Ethical Consideration}

The analysis was based on secondary data. All identifies for the participants were removed. The Institutional Review Board of ICF Macro International approved the survey procedures and instruments. 


\section{Variables and Measures}

The dependent variable was marital status categorised into married and consensual union (living together). The independent variables included individual-level and contextual factors selected based on past studies. The individual-level explanatory variables were current age, age gap between spouses (wife older, husband older with 0-3 years, 4-9 years, 10-19 years and 20+ years), level of education (no education, primary, secondary/higher), partner's level of education (no education, primary, secondary and higher), education gap between spouses (wife more educated, same, and husband more educated), occupation (not working, white-collar, sales/services, agriculture, manual/domestic), number of union (once, and more than once), type of union (monogamous or polygynous), religion (Christianity, Islam, and others), premarital birth (No and Yes), age at first sex (at first union, $<=15$ years, 16-19 years and 20-48 years), number of sons (no son, I, 2, 3+ sons), household wealth (poorest, poorer, middle, richer and richest), marriage cohort (year of first cohabitation - 1960-1989, 1990-1999, 2000-2010, and 20II-20I4), and language group (Francophone and Anglophone).

Community-level (contextual) variables were place of residence, community level of poverty, female education and level of divorce and separation. Place of residence was urban and rural. Other community variables were generated by aggregating individual-level variables. Community level of poverty was categorised as low, middle and high. Community female education was the proportion of women who had attained secondary and higher education in the PSU, grouped as low, middle and high; community level of divorce and separation was the proportion of women whose marriages dissolved through divorce or separation, categorised into low middle and high. Community level of divorce and separation was included as a measure of prevalence and social acceptability of non-marital forms. Where divorce and separation is high, consensual union is also expected to be high given that people who want to avoid divorce may remain in consensual union (Jensen \& Calusen, 2003). Cross tabulation of this variable and marital status (table not shown) shows that consensual union increases as the level of divorce and separation in a community increases

\section{Analytical Approach}

Data analysis was conducted at three levels: univariate, bivariate and multivariate. Univariate and multivariate analyses were based on the most recent surveys. To examine the trends, three successive surveys, except in Sierra Leone and Togo were used, categorised into three ranks: rank I- most recent
(20I0-20I4), rank 2 - next to most recent (20032008), and rank 3 - second to most recent (19972003). The terminal year for rank 3 is 2003 and rank 2 begins from 2003 because rank 3 for Ghana and Nigeria was 2003, whereas rank 2 for Burkina Faso was 2003. The univariate analysis involved use of percentages to describe the study population, levels and trends of consensual union in the sub-region. Prevalence of consensual union was computed as a percentage of the total population of all women in union. Bivariate analysis involved cross-tabulation and use of Pearson chi-square test to examine association between the outcome and explanatory variables. At the multivariate level, random and fixed effects logistic regression models were used to examine individual and contextual variables associated with consensual union in West Africa. To partition the total variance into individual and community components, a two- level binary logistic regression model was estimated. The fixed effects modelled associations whereas random effects modelled variations. Multilevel modelling was appropriate for the analysis given that the study was interested in the extent to which individual-level and neighbourhood (community) features are related to consensual union. Measures of association, such as odds ratio do not reflect variations in the outcome variable across and within communities where the individual women live. Thus, measures of variation in multilevel modelling, such as intra-class correlation (or variance partition coefficient) and proportional change in variance, were employed to present contextual factors associated with consensual union (Merlo et al., 2006). Also, in multi-stage sampling, such as was used in DHS, respondents from same geographical area (community) are likely to be more similar than respondents from different areas. Multilevel modelling accounts for the hierarchical structure of the DHS data, individual women nested in EAs and clustering at different levels.

An empty model which contained no explanatory variable was estimated first to present variance in consensual union among clusters (communities) and tests the significance of the cluster level variance (Merlo et al., 2006). In addition to the empty model, three models were fitted. Model I included only individual-level variables, model 2 contained community-level variables, and model 3 was the full model containing all the individual and community variables. These models were fitted to examine the independent association between community and individual-level variables and the likelihood of being in a consensual union. Variables included in each model were selected through forward stepwise regression.

Each model estimated the variance of random intercepts for the cluster and the intra class 
correlation coefficients (ICC) or variance partition coefficients (VPC). The random intercepts reflect the degree of heterogeneity between clusters whereas ICC reflects the degree of homogeneity within a cluster (Griffiths, Madise, Whitworth, \& Matthews, 2004; Kaggwa, Diop, \& Storey, 2008). Low ICC denotes that the within-cluster variation accounts for a larger part of the variance (Kaggwa et al., 2008). ICC in this study was computed using the same general formula as in linear models except that $\sigma_{e}^{2}=\pi^{2} / 3$,

$$
\begin{aligned}
& \text { Therefore } \\
& \text { ICC }=\frac{\sigma_{u}^{2}}{\sigma_{u}^{2}+\pi^{2} / 3}
\end{aligned}
$$

Where $\sigma_{u}^{2}$ is the variance at the community level, and $\pi^{2} / 3$ is the fixed variance at individual level (Rodriguez \& Elo, 2003). Precision of the random effects was measured using standard errors (SE) of the covariates, and goodness-of-fit for the models was measured using Akaike Information Criterion (AIC) and Bayesian Information Criterion (BIC). These are common measures for comparing maximum likelihood models. Model with the smaller value of the information criterion is viewed as better.

\section{Results}

Table I presents percent distribution of the study population by selected background characteristics. Slightly above 10 percent of the study population were in consensual union. Most of the respondents had no education $(64.6 \%)$, and many were not working. Among those who worked, the majority were engaged in sales/services or agriculture as selfemployed or employee. More than three-quarter of the respondents had married only once ( $85.6 \%)$, and slightly above a third (34\%) were in polygynous union. With respect to household wealth index, there was little difference between the proportion of women in the poor and richer quintiles. Close to half of the respondents entered their first union between 2000 and 2010, and many were from the Francophone countries, and resided in rural areas. Most respondents lived in communities with high levels of poverty, female education, divorce and separation. Levels and trends of consensual union in West Africa, the two linguistic blocs and each country are presented in figures I-3 below.

Table I: Description of the study population by selected characteristics, most recent DHS

\begin{tabular}{|l|l|l|}
\hline Characteristic & Frequency & Percent \\
\hline Marital Status (I23,047) & 110,247 & 89.60 \\
Married & 12,800 & 10.40 \\
Consensual union & & \\
\hline Education (I23,032) & 79.541 & 64.65 \\
No education & 21,007 & 17.07 \\
Primary & 22,484 & 18.28 \\
\hline Secondary/Higher & & \\
\hline Occupation (I22,804) & 40,568 & 33.03 \\
Not working & 3,457 & 2.82 \\
White-collar & 38,071 & 31.00 \\
Sales/services & 29,820 & 24.28 \\
Agriculture & 10,888 & 8.87 \\
Manual/domestic & & \\
\hline Number of union (I22,46I) & 104,834 & 85.61 \\
Once & 17,627 & 14.39 \\
More than once & & \\
\hline Type of union (I22,847) & 80,753 & 65.73 \\
Monogamy & 42,094 & 34.27 \\
\hline Polygyny & & \\
\hline Household wealth index (I23,047) & $23,76 I$ & 19.31 \\
Richest & 24,447 & 19.87 \\
Richer & 24,140 & 19.62 \\
Middle & 25,187 & 20.47 \\
Poorer & 25,512 & 20.73 \\
\hline Poorest & & \\
\hline Year of It cohabitation (I23,047) & 20,496 & 16.66 \\
\hline I960-I989 & & \\
\hline
\end{tabular}




\begin{tabular}{|l|l|l|}
\hline I990-I999 & $38,5 I 2$ & 31.30 \\
$2000-2010$ & 56,388 & 45.83 \\
$20 I I-20 I 4$ & $7,65 I$ & 6.22 \\
\hline Language group (I23,047) & 73,608 & 59.82 \\
Francophone & 49,439 & 40.18 \\
\hline Anglophone & & \\
\hline Place of residence (I23,047) & 40,837 & 33.19 \\
Urban & 82,210 & 66.81 \\
Rural & & \\
\hline Community level of poverty (II8,904) & 12,150 & 10.22 \\
Low & $44,79 I$ & 37.67 \\
Middle & 61,963 & 52.11 \\
High & & \\
\hline Community female education (I22,943) & 18,560 & 15.10 \\
Low & 35,289 & 28.70 \\
Middle & 69,094 & 56.20 \\
High & & \\
\hline Community-level of divorce/separation (II8,592) & 15,499 & 13.07 \\
Low & 41,579 & 35.06 \\
Middle & 61,514 & 51.87 \\
\hline High & \\
\hline
\end{tabular}

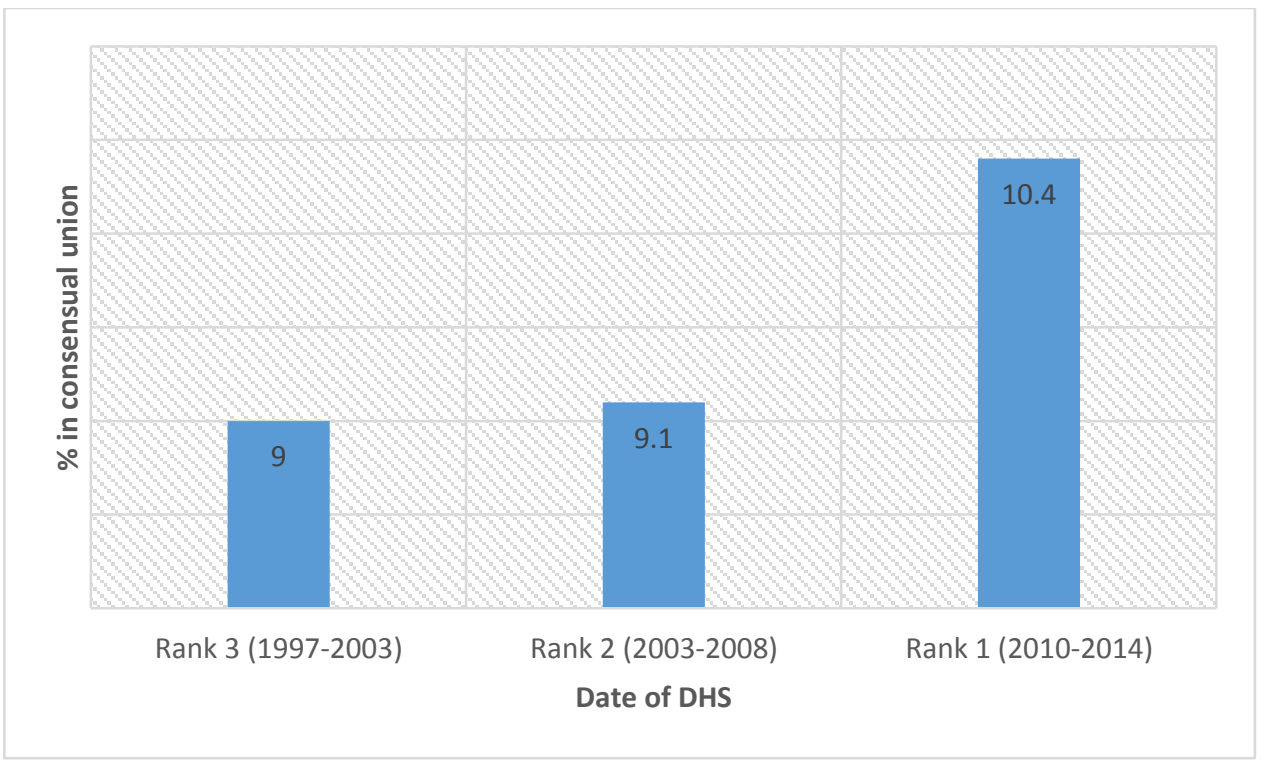

Figure I: Levels and trends of consensual union in West Africa (DHS, 1997-20I4)

Consensual union in West Africa increased from $9.0 \%$ in rank $3(1997-2003)$ to $10.4 \%$ in the first rank (20I0-20|4), about $15.5 \%$ increase. There was variation in the prevalence and trends of consensual union across countries (Figures $2 \& 3$ ). The highest prevalence of consensual union was in Liberia. High levels of consensual union were observed in Cote d'Ivoire, Ghana and Benin. Patterns of consistent increase in consensual union were obvious in Cote d'Ivoire,
Togo and Ghana. For instance, in Ghana, there was $72.3 \%$ increase between DHS rank 3 and 2, and I $3.4 \%$ increase between rank 2 and I. Lowest levels of consensual union were in Niger, Senegal and Nigeria. At the bivariate level of analysis, using cross tabulation and Pearson chi-square, all the independent variables were significantly associated with consensual union, expect language group (Table not shown). 


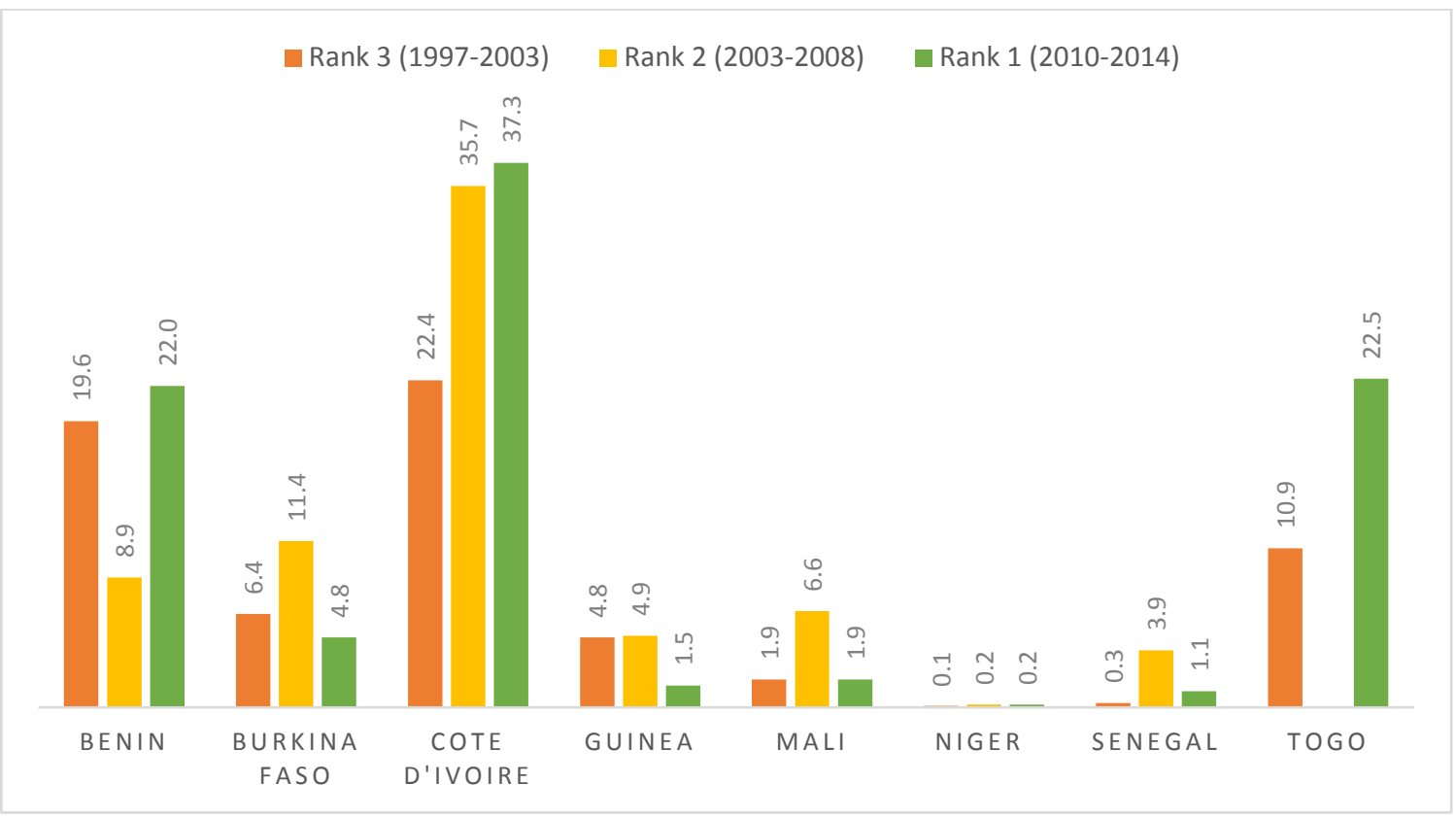

Figure 2: Levels and Trends of consensual union in Francophone West African countries

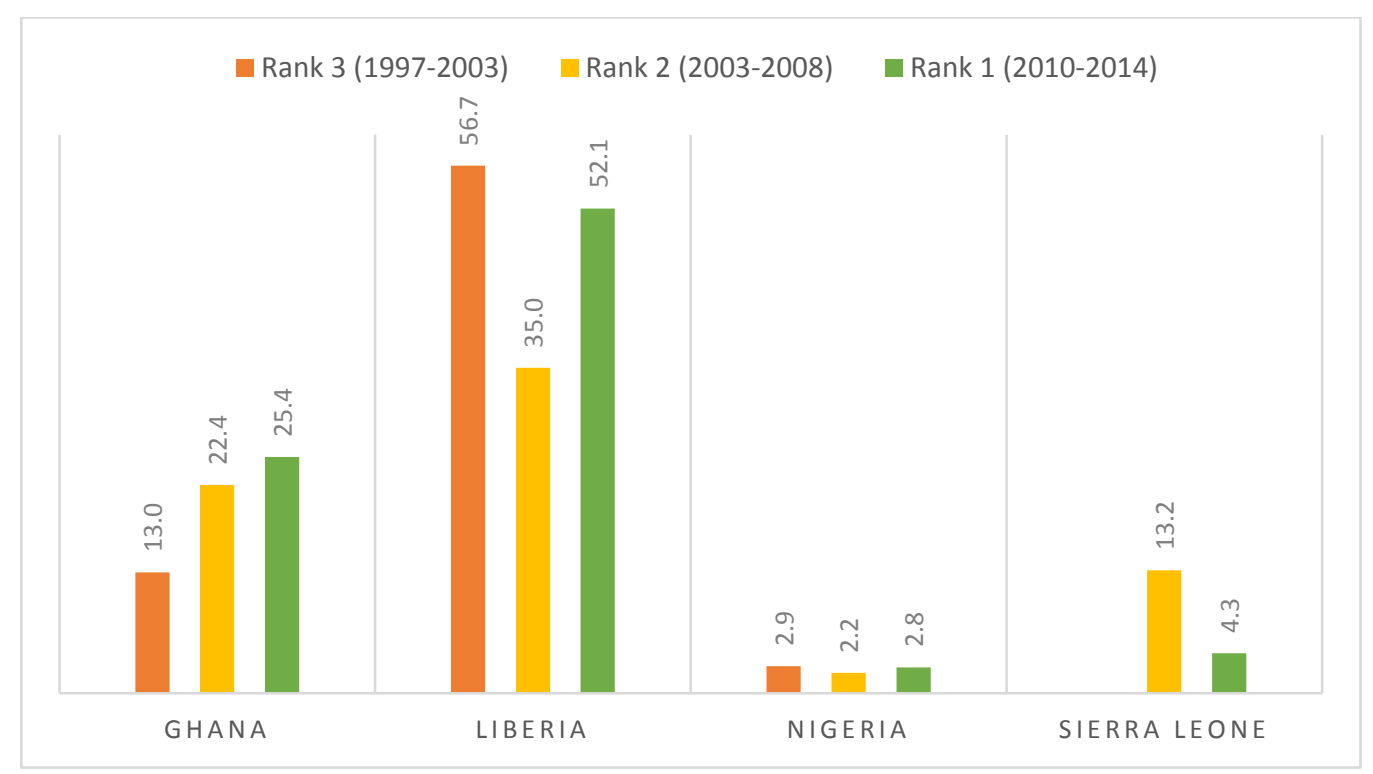

Figure 3: Levels and Trends of consensual union in Anglophone West African countries

\section{Multi-level Analysis}

Results of the multilevel models of individual-level and community-level factors associated with consensual union in West Africa are presented in Table 2 below.

\section{Individual-level Effects}

Results of the multilevel model fixed effect revealed that several individual-level variables were significantly associated with the odds of forming a consensual union in West Africa. Estimation with only

individual-level variables (Model I) showed an inverse significant association between all age groups and consensual union, but the effect size decreased with age. Age gap between women and their partners was also negatively associated with consensual union. Relative to women who were older than their partners, those who were same age or younger than their partners were significantly less likely to be in consensual union. 
Table 2. Multilevel Logistic regression models of individual and contextual predictors of consensual union in West Africa, DHS 20I0-2014

\begin{tabular}{|c|c|c|c|c|}
\hline Variable & Null Model & $\begin{array}{l}\text { Model } \\
\text { (Individual } \\
\text { variables) } \\
\text { OR(95\% Cl) }\end{array}$ & \begin{tabular}{ll|} 
Model & 2 \\
(Community & \\
variables) & \\
OR(95\% Cl) &
\end{tabular} & $\begin{array}{l}\text { Model } 3 \text { (Full) } \\
\text { OR(95\% Cl) }\end{array}$ \\
\hline $\begin{array}{l}\text { Age } \\
\text { I5-19(RC) } \\
20-24 \\
25-29 \\
30-34 \\
35-39 \\
40-44 \\
45-49\end{array}$ & & $\begin{array}{l}0.86(0.77-0.96) * \\
0.7 I(0.64-0.80)^{*} * * \\
0.64(0.56-0.72)^{* * *} \\
0.58(0.50-0.66)^{* * *} \\
0.54(0.46-0.63)^{* * *} \\
0.40(0.33-0.48)^{* * *}\end{array}$ & & $\begin{array}{l}0.85(0.76-0.95)^{* *} \\
0.71(0.63-0.80)^{* * *} \\
0.64(0.56-0.72)^{* * *} \\
0.57(0.50-0.66)^{* * *} \\
0.54(0.46-0.63)^{* * *} \\
0.39(0.32-0.47)^{* * * *}\end{array}$ \\
\hline $\begin{array}{l}\text { Spousal age gap } \\
\text { Wife older (RC) } \\
\text { Same/wife younger } 0-3 \\
\text { years } \\
\text { Wife younger } 4-9 \text { years } \\
\text { Wife younger } 10-19 \text { years } \\
\text { Wife younger } 20+\end{array}$ & & $\begin{array}{l}0.75(0.67-0.84)^{* * * *} \\
0.57(0.51-0.63)^{* * * *} \\
0.40(0.36-0.45)^{* * * *} \\
0.37(0.32-0.42)^{* * *}\end{array}$ & & $\begin{array}{l}0.76(0.68-0.86)^{* * * *} \\
0.56(0.50-0.63)^{* * * *} \\
0.39(0.35-0.44)^{* * * *} \\
0.36(0.31-0.4 I)^{* * *}\end{array}$ \\
\hline $\begin{array}{l}\text { Education } \\
\text { No education (RC) } \\
\text { Primary } \\
\text { Secondary/Higher }\end{array}$ & & $\begin{array}{l}\text { I. } 3 \text { I (I.22-I.4I)**** } \\
\text { I. } .40(\mid .28-1.54)^{* * * *}\end{array}$ & & 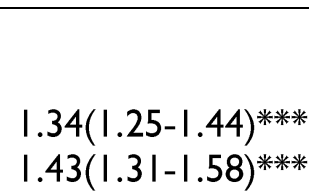 \\
\hline $\begin{array}{l}\text { Partner's education } \\
\text { No education (RC) } \\
\text { Primary } \\
\text { Secondary } \\
\text { Higher }\end{array}$ & & $\begin{array}{l}\text { I.40(I.28-1.53)*** } \\
\text { I.67(I.49-1.86)*** } \\
\text { I.01(0.86-1.19) }\end{array}$ & & $\begin{array}{l}1.44(1.31-1.58)^{* * * *} \\
1.73(1.55-1.93)^{* * * *} \\
1.06(0.89-1.25)\end{array}$ \\
\hline $\begin{array}{l}\text { Spousal education gap } \\
\text { Wife more (RC) } \\
\text { Same } \\
\text { Husband more }\end{array}$ & & $\begin{array}{l}0.88(0.80-0.96) * * \\
\text { I.24(I.I2-I.38)*** }\end{array}$ & & $\begin{array}{l}0.90(0.82-0.98)^{*} \\
1.24(\mathrm{I} . \mathrm{I}-\mathrm{I} .38)^{* * * *}\end{array}$ \\
\hline $\begin{array}{l}\text { Occupation } \\
\text { Not working (RC) } \\
\text { White-collar } \\
\text { Sales/services } \\
\text { Agriculture } \\
\text { Manual/domestic }\end{array}$ & & $\begin{array}{l}0.63(0.53-0.74)^{* * * *} \\
0.90(0.84-0.95)^{* * *} \\
0.91(0.85-0.98)^{*} \\
0.60(0.54-0.66)^{* * *}\end{array}$ & & $\begin{array}{l}0.62(0.52-0.74)^{* * * *} \\
0.89(0.84-0.95)^{* * *} \\
0.96(0.89-1.02) \\
0.59(0.53-0.65)^{* * *}\end{array}$ \\
\hline $\begin{array}{l}\text { Number of union } \\
\text { Once (RC) } \\
\text { More than once } \\
\end{array}$ & & $2.06(1.94-2.19)^{* * * *}$ & & $2.08(1.95-2.21)^{* * *}$ \\
\hline $\begin{array}{l}\text { Type of union } \\
\text { Monogamy (RC) } \\
\text { Polygyny } \\
\end{array}$ & & $0.79(0.74-0.83)^{* * * *}$ & & $0.79(0.75-0.84)^{* * *}$ \\
\hline $\begin{array}{l}\text { Religion } \\
\text { Christianity (RC) } \\
\text { Islam } \\
\text { Others }\end{array}$ & & $\begin{array}{l}0.56(0.52-0.61)^{* * *} \\
1.37(1.30-1.45)^{* * *}\end{array}$ & & $\begin{array}{l}0.57(0.52-0.6 \mathrm{I})^{* * * *} \\
1.34(\mathrm{I} .26-\mathrm{I} .4 \mathrm{I})^{* * * *}\end{array}$ \\
\hline $\begin{array}{l}\text { Premarital birth } \\
\text { No }(R C) \\
\text { Yes }\end{array}$ & & $\mathrm{I} .52(\mathrm{I} .43-\mathrm{I} .6 \mathrm{I})^{* * * *}$ & & $1.5 \mathrm{I}(\mathrm{I} .4 \mathrm{I}-\mathrm{I} .60)^{* * *}$ \\
\hline
\end{tabular}




\begin{tabular}{|c|c|c|c|c|}
\hline $\begin{array}{l}\text { Age at first sex } \\
\text { At first union }(\mathrm{RC}) \\
<=15 \\
16-19 \\
20-48\end{array}$ & & $\begin{array}{l}2.96(2.77-3.15)^{* * * *} \\
2.90(2.72-3.08)^{* * *} \\
2.42(2.21-2.66)^{* * *}\end{array}$ & & $\begin{array}{l}2.9 \mathrm{I}(2.73-3 . \mathrm{II})^{* * * *} \\
2.8 \mathrm{I}(2.64-3.00)^{* * *} \\
2.28(2.06-2.5 \mathrm{I})^{* * *}\end{array}$ \\
\hline $\begin{array}{l}\text { Number of sons } \\
\text { No son }(R C) \\
\text { I son } \\
2 \text { sons } \\
3+\text { sons }\end{array}$ & & $\begin{array}{l}0.93(0.87-0.99)^{*} \\
0.88(0.82-0.95)^{* *} \\
0.83(0.76-0.91)^{* * *}\end{array}$ & & $\begin{array}{l}0.92(0.86-0.98)^{*} \\
0.87(0.81-0.94)^{* *} \\
0.82(0.75-0.90)^{* * *}\end{array}$ \\
\hline $\begin{array}{l}\text { Household wealth index } \\
\text { Richest(RC) } \\
\text { Richer } \\
\text { Middle } \\
\text { Poorer } \\
\text { Poorest }\end{array}$ & & 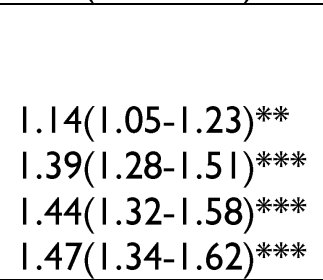 & & $\begin{array}{l}\mathrm{I} .23(\mathrm{I} . \mathrm{I} 2-\mathrm{I} .34)^{* * * *} \\
\mathrm{I} .65(\mathrm{I} .50-\mathrm{I} .8 \mathrm{I})^{* * *} \\
\mathrm{I} .82(\mathrm{I} .64-2.0 \mathrm{I})^{* * *} \\
\mathrm{I} .88(\mathrm{I} .69-2.09)^{* * *}\end{array}$ \\
\hline $\begin{array}{l}\text { Year of } \text { I }^{\text {st }} \text { cohabitation } \\
1960-1989(\mathrm{RC}) \\
1990-1999 \\
2000-2010 \\
2011-2014\end{array}$ & & $\begin{array}{l}\mathrm{I} . \mathrm{I} I(\mathrm{I} .00-\mathrm{I} .23)^{*} \\
\mathrm{I} .20(\mathrm{I} .06-\mathrm{I} .37)^{* *} \\
\mathrm{I} .68(\mathrm{I} .42-\mathrm{I} .98)^{* * *}\end{array}$ & & $\begin{array}{l}\mathrm{I} . \mathrm{I} \mathrm{I}(\mathrm{I} .00-\mathrm{I} .24)^{*} \\
\mathrm{I} .24(\mathrm{I} .08-\mathrm{I} .4 \mathrm{I})^{* *} \\
\mathrm{I} .74(\mathrm{I} .47-2.06)^{* * *}\end{array}$ \\
\hline $\begin{array}{l}\text { Language group } \\
\text { Francophone (RC) } \\
\text { Anglophone }\end{array}$ & & $0.9 \mid(0.86-0.96)^{* *}$ & & $0.95(0.90-1.00)$ \\
\hline $\begin{array}{l}\text { Place of residence } \\
\text { Urban (RC) } \\
\text { Rural }\end{array}$ & & & $0.6 I(0.58-0.63)$ **** & $0.67(0.62-0.7 \mathrm{I})^{* * * *}$ \\
\hline $\begin{array}{l}\text { Community level of } \\
\text { poverty } \\
\text { Low (RC) } \\
\text { Middle } \\
\text { High }\end{array}$ & & & $\begin{array}{l}0.29(0.24-0.35)^{* * * *} \\
0.36(0.29-0.43)^{* * * *}\end{array}$ & $\begin{array}{l}0.36(0.30-0.43)^{* * * *} \\
0.39(0.31-0.47)^{* * * *}\end{array}$ \\
\hline $\begin{array}{l}\text { Community female } \\
\text { education } \\
\text { Low }(R C) \\
\text { Middle } \\
\text { High } \\
\end{array}$ & & & $\begin{array}{l}1.06(0.90-1.25) \\
1.28(1.06-1.54)^{* *}\end{array}$ & $\begin{array}{l}\mathrm{I} .12(0.94-\mathrm{I} .33) \\
\mathrm{I} .30(\mathrm{I} .07-\mathrm{I} .58)^{* *}\end{array}$ \\
\hline $\begin{array}{l}\text { Community-level of } \\
\text { divorce/separation } \\
\text { Low (RC) } \\
\text { Middle } \\
\text { High } \\
\end{array}$ & & & $\begin{array}{l}\text { I.36(I.|4-I.62)**** } \\
\mathrm{I} .80(\mathrm{I} .45-2.22)^{* * * *} \\
\end{array}$ & $\begin{array}{l}\mathrm{I} .40(\mathrm{I} . \mathrm{I} 7-\mathrm{I} .67)^{* * * *} \\
\mathrm{I} .62(\mathrm{I} .30-2.02)^{* * *}\end{array}$ \\
\hline Random effects & & & & \\
\hline $\begin{array}{l}\text { Community-level variance } \\
\text { (SE) }\end{array}$ & $0.727(0.047)^{* * *}$ & $0.670(0.048)^{* * * *}$ & $0.459(0.033) * * *$ & $0.440(0.035)^{* * * *}$ \\
\hline ICC (\%) & 18.1 & 16.9 & 12.2 & 11.8 \\
\hline PCV (\%) & Ref & 7.8 & 36.9 & 39.5 \\
\hline Log likelihood & -38498.73 & $-27|4| .6$ & -36251.54 & -25520.12 \\
\hline Model fit statistics & & & & \\
\hline $\mathrm{AIC}$ & 77001.47 & 54379.19 & 72521.09 & 51150.25 \\
\hline $\mathrm{BIC}$ & 77020.91 & 54835.93 & 72608.1 & 51670.33 \\
\hline
\end{tabular}

$O R$, odds ratio; $\mathrm{Cl}$ confidence interval; SE standard error; ICC intra-class (community)correlation; PCV proportional change in variance; AIC Akaike information criterion; $R C$ - Reference category; ${ }^{*} p<0.05$; ** $p, 0.01$; **** $p<0.001$ 
Respondents who attainted any level of education were more likely to be in consensual union than those who had no education. Primary education significantly increased the odds of consensual union by $31 \%$ whereas secondary and higher education increased it by $40 \%$. Partner's level of education showed a similar result to respondents' education. Women whose partners had primary and secondary education were more likely to be in consensual union than those whose partners were uneducated, but there was no significant difference between higher education and consensual union. Relative to unions where wives had more education, consensual union was more likely for respondents whose partners had more years of schooling (OR I.24 $p<.00$ I), whereas same level of education decreased the odds of consensual union by $12 \%$. In regard to occupation, respondents who worked in any type of occupation were significantly less likely than those who did not work to be in consensual union.

Women who had been in a marital union more than once were more likely than those who were in their first union to be in consensual union (OR 2.06 $\mathrm{p}<.00 \mathrm{I})$. Lower odds of consensual union were associated with polygynous than monogamous union (OR $0.79 \mathrm{p}<.00 \mathrm{I}$ ). Compared to Christians, Muslims were less likely to be in consensual union (OR 0.56 $\mathrm{p}<.00 \mathrm{I})$ whereas others in traditional and other religions were more likely to be in consensual union (OR I.37 p <.00I) than Christians. Respondents who had premarital births were more likely than those who did not, to be in consensual union (OR I.52 $\mathrm{p}<.00 \mathrm{I}$ ). Respondents whose sexual debut took place before first union were more likely to form consensual union than those whose first sexual intercourse was in their first union. Number of sons was inversely related to consensual union, those who had one or more sons were significantly less likely to be in consensual union than those who had no sons; the likelihood and level of significance increased with higher number of sons. Relative to respondents in the richest household wealth quintile, those in richer, middle, poorer, and poorest quintiles were more likely to be in consensual union. The size of the positive relationship increased with lower household wealth status. With regard to marriage cohort, respondents who married from 1990 to 2014 were more likely than those who married earlier to be in consensual union. The positive association was stronger and larger from the 2000s. For instance those who married between $20 \mathrm{II}$ and $20 \mathrm{I} 4$ were $68 \%$ more likely to be in consensual union, whereas those who married in the 1990s were only II\% more likely to be in consensual union. Respondents in Anglophone West Africa were less likely than their
French-speaking counterparts to be in consensual union.

In the full model (Model 3) that contained the individual and community variables, the direction of association remained, and the effect size attenuated or increased slightly for all the individual-level variables, except Language group where the significant difference between Francophone and Anglophone countries was lost.

\section{Community-level effect}

Model 2 contained only community variables. The results showed that residing in a rural area decreased the likelihood of forming a consensual union by $39 \%$ compared to urban residence. Respondents who lived in communities with high proportion of educated women were significantly more likely to be in consensual union (OR I.28 $\mathrm{p}<.0 \mathrm{I}$ ) than those in communities where level of female education was low. Residence in communities with middle and high level of poverty was negatively associated with consensual union. The odds of consensual union was higher for respondents who resided in communities with middle and high proportion of divorced and separated women, compared to communities with low divorce and separation. For instance, the odds of consensual union in communities with high proportion of divorced and separated women was I.80 $(p<.00 \mathrm{I})$. In the full model when individual variables were adjusted, all the significant relationship between consensual union and the community variables remained and in the same direction, but the effect size increased in all cases except for high proportion of divorced and separated women category where the effect size attenuated.

Random effect results (Table 2) showed there was significant variation in the odds of being in a consensual union across communities in West Africa ( $\tau=0.727, p<0.00 I$ ). Compared to the null model, the variation across communities reduced and remained significant in the subsequent models that contained only individual variables (Model I), community variables (Model 2) and the full model (Model 3). The intra-community correlation (ICC) in the null model indicated that $18.1 \%$ of the individual variation in the odds of being consensual union was related to the community level and may be attributable to contextual factors. The ICC decreased to $16.9 \%$ when only individual variables were fitted in model $\mathrm{I}, 12.2 \%$ in model 2 for only community variables, and $11.8 \%$ in the full model. The proportional change in variance (PCV) when individual variables were added (Model I) was $7.8 \%$, the subsequent PCV for model with only community variables was $36.9 \%$ indicating that community-level variables explained more of the clustering of 
consensual union across communities than individuallevel variables. The PCV for the full model was $39.5 \%$. Goodness-of-fit measures, AIC and BIC, became lower with subsequent models, indicating that models I to 3 were better than the null model. However, the full model that contained both individual and contextual variables had the best fit with the lowest AIC and BIC.

\section{Discussion of the Findings}

This paper examined the levels, trends and factors associated with consensual union in West Africa. Results showed a rising trend in consensual union in the sub-region. The rising trend may be related to the influx of modern ideals, high levels of poverty, unemployment especially male unemployment and underemployment. This finding corroborates past studies that show increasing levels of consensual union in developing regions (Martin, 2002).

Confirming past studies, many individual and contextual factors were significantly associated with consensual union in West Africa. Consensual union was significantly less likely in Anglophone than Francophone West Africa, although the significant difference was not large. This confirms the pattern in Canada observed in (Laplante, 20l4) where consensual union was more prevalent among Frenchspeaking Quebec than other regions. Current age of respondents was inversely related to consensual union, however, the effect size was larger for younger women, and those who married between 1990 and 2014 were significantly more likely to be in consensual union than those who married before the 1990s. This result is similar to the findings in (Martin (2002) and corroborates other studies that associate consensual union with younger persons (Adjamagbo et al., 20I4; Kamgno \& Mengue, 20I4). Women who were same age or younger than their partners were less likely to be in consensual union. This suggests that consensual union was significantly more common in couples where the wife is older. Consensual union in this case may be a way to escape the stigma associated with prolonged or permanent singlehood for women (Ntoimo \& Isiugo-Abanihe, 20I4).

Unlike in Latin America where consensual union was associated more with women who had no education (Martin, 2002), in West Africa, women who had attained any level of education were more likely than their uneducated counterparts to be in consensual union, confirming past studies in subSaharan Africa (Kamgno \& Mengue, 20I4; LeGrand \& Younoussi, 2009). This study also shows that women whose partners attained primary and secondary education were more likely to be in consensual union, but attainment of tertiary education was statistically insignificant. Given the relevance of men's socioeconomic status in the type of union that is formed, and level of education being a proxy for socioeconomic status, it is expected that couples of low socioeconomic status should be more in consensual union than those who attained any level of education. However, it is likely that these women and men who attained any level of education in West Africa are more likely than their uneducated counterparts to imbibe modern individualistic ideals that encourage consensual union (van de Kaa, 1987), and resist bride wealth marriage if they cannot afford it. Also, the result for partner's education suggests that the educated women in West Africa who were more likely to be in consensual union may be more of those who attained primary and secondary education, given that men are more likely to have partners who have same or lower education (Kalmijn, 1998). Also, only $3 \%$ of women in this study attained higher education, which indicates that more of those in consensual union are those who attained primary and secondary education. Recent empirical evidence shows that more highly educated women and men are marrying formally and remaining married than their less educated counterparts (McLanahan, 2004; Musick, Brand, \& Davis, 20I2).

Engagement in any occupation significantly decreased the likelihood of consensual union in West Africa. Although most women in sub-Saharan Africa work in the informal sector, (Chant \& Pedwell, 2008; UNDP, 2014), women's income is increasingly important in enhancing the economic status of a family (Kalmijn, 1998). Better family economic status will encourage couples to formalise their union, particularly in meeting the requirements of bride wealth or dowry. Meekers (1992) noted that increasing consensual union in Africa due to decline in lineage control is expected to be more prevalent among women with modern characteristics, such as education and formal employment. The current analysis confirms Meekers' observation as regards education, but shows that occupational status of women had no positive association with consensual union in West Africa. Meekers observation on occupation may likely become evident as more women in the sub-region are engaged in the formal sector.

Respondents who had married more than once were more likely to be in consensual union than those who were in their first union. Second and higher order marital unions majorly result from marital disruption due to divorce, separation or widowhood; and such women are more likely to compromise traditional norms of formalising marital unions in order to be re-partnered. This finding supports previous studies in West Africa and other countries (LeGrand \& Younoussi, 2009; Castro 
Martin, 2002; Finnas, 1995). Consensual union was significantly less likely in polygynous unions and among Muslims. Noteworthy is that the lowest prevalence of consensual union was also in Muslimdominated countries in the region, and polygyny is more prevalent among Muslims than Christians. Finding on religion is similar to LeGrand \& Younoussi's (2009) finding in Burkina Faso. Premarital birth increased the likelihood of consensual union in West Africa. The stigma associated with premarital pregnancy and birth pressurises girls and their parents to giving the girls out to undesired unions, such as consensual union (Ringsted, 2004). Age at first sex was also a significant positive determinant of consensual union in the sub-region. Respondents whose sexual debut took place before their first union were more likely to be in consensual union. This relationship may be because women who initiate sex before marriage are more likely to be cohabiting with an intimate partner. Among some Burkinabè ethnic groups, premarital sexual relations take the form of consensual unions (LeGrand \& Younoussi, 2009). A similar result was obtained in Martin (2002) in some Latin American countries.

The presence of sons decreased the odds of consensual union in West Africa. This confirms past studies that the presence of children, particularly sons encourages men to concretise consensual relationships (Isiugo-Abanihe, 2000), whereas lack of a live birth, particularly of sons increases the risk of remaining in consensual union (Adjamagbo et al., 20/4). Children, particularly sons are viewed as necessary to perpetuate one's lineage and for old age security (Ela, 1995; Rwenge, 2002).

An important finding is the relationship between household wealth and consensual union. Relative to the richest quintile, all categories of lower household wealth were significantly more likely to be in consensual union. Due to the importance attached to bride wealth in many countries in the sub-region and the increasing significance of religious wedding, intending couples may remain in consensual union because they cannot afford the high cost of formal marriage (Arnaldo, 2004; Kamdem, 2006; Kamgno \& Mengue, 2014; Locoh, 2002). This finding suggests the need for programmatic interventions to encourage formalisation of union without expensive marriage ceremonies.

With regard to community-level factors, there was significant variation in the odds of being in a consensual union across communities in West Africa. However, the low ICC indicates that withincommunity variation accounts for a large part of the variance in the odds of consensual union in West Africa. Women in the rural areas were less likely to be in consensual union. Influence of social change and cultural modernism is more prominent in urban than rural areas in many countries in West Africa, thus consensual union thrive in urban centres (Kamgno \& Mengue, 2014; LeGrand \& Younoussi, 2009; Meekers, 1992; Thiriat, 1999). The research revealed lower odds of consensual union in communities with middle and high proportion of poor women. This is not surprising given that a man's socioeconomic status not the woman's significantly determine whether a union is formalised or not (Kalmijn, 20 I I). High proportion of women who were educated in a community increased the odds of consensual union, supporting some previous studies in sub-Saharan Africa (Meekers, 1992, 1994; Kamgno \& Mengue, 2014; LeGrand \& Younoussi, 2009) Residence in a community where a high proportion of women attained secondary and tertiary education is likely to influence nuptiality behaviour of even the uneducated women. The proportion of divorced and separated women in a community was a significant determinant of consensual union in West Africa. High proportion of divorced and separated women may be an indication of high tolerance of non-traditional family form, and declining lineage control on individual marital behaviour, which according to Meekers (1992) increases the prevalence of consensual union in Africa.

\section{Limitations of the study}

The current study had limitations. One, community poverty level would be best measured with proportion of men and women who are poor. Also, proportion of men who are poor in a community would have provided more insight, given the role of men's economic status in whether a union is consensual or formal. We suggest that these measures be used in future studies. Pooled data generated a large study population which resulted in small differences being statistically significant. Also, the cross-sectional nature of the data does not allow for inference on causality. Thus, the results in this research represent factors associated with consensual union at a particular period. In spite of these limitations, this study highlights factors associated with consensual union in West Africa, and categories of women who are more likely to be in consensual unions.

\section{Conclusion}

This study revealed that a growing proportion of women in West Africa are in consensual union. Given the health and welfare implications of consensual union, the findings underscore the need for policies and programmatic interventions to protect women in consensual unions, and to extend the benefits of formal marriage to consensual union in case of break 
up. Other individual, family, community and national level factors which were beyond the scope of the current analysis may be related to consensual union in the sub-region. Therefore, we suggest further studies on consensual union in West Africa, and other countries in sub-Saharan Africa. Studies that will make use of longitudinal data will be useful to reveal the predictors of consensual union over time.

\section{Acknowledgement}

The authors acknowledge the support of the DSTNRF Centre of Excellence in Human Development, South Africa. Opinions expressed and conclusions arrived at are those of the authors and not necessarily to be attributed to either the Centre of Excellence in Human Development.

\section{References}

Adjamagbo, A., Antoine, P., Toudéka, M., Kpadonou, N., \& Fageac, E. (20I4). Mise en couple et devenir des unions: comparaison de deux capitales ouestafricaines, Cotonou et Lomé. Paris: AIDELF, 2014, 25 P. Multigr. Colloque International de I'AIDELF, 18., Bari (ITA), Du 26 Au 29 Mai, 25p. Retrieved from http://www.documentation.ird.fr/hor/fdi:01006/6 16

Andersson, G. (2004). Children's experience of family disruption and family formation: Evidence from 16 FFS countries. Vienna Yearbook of Population Research, 313-332.

Antoine, P. (2007). Comportements matrimoniaux au Sénégal à l'interface des traditions, de l'Islam, de la colonisation et de la loi (du XVIIlème au XXème siècle). Presented at the Croisés au Sud et au Nord.

Arnaldo, C. (2004). Ethnicity and Marriage Patterns in Mozambique. African Population Studies, 19(1), 143-164.

Bracher, M., Santow, G., Morgan, S. P., \& Trussell, J. (1993). Marriage dissolution in Australia: Models and explanations. Population Studies, 47(3), 403425.

Browning, C. R., Leventhal, T., \& Brooks-Gunn, J. (2005). Sexual initiation in early adolescence: The nexus of parental and community control. American Sociological Review, 70(5), 758-778.

Chant, S., \& Pedwell, C. (2008). Women, Gender and the Informal Economy: An Assessment $f$ ILO Research and suggested ways forward (Discussion paper). Geneva, Switzerland: ILO.
De Jong Gierveld, J. (2004). Remarriage, unmarried cohabitation, living apart together: Partner relationships following bereavement or divorce. Journal of Marriage and Family, 66(I), 236-243.

Dike, V. E. (2002). The Osu Caste System in Igboland: Discrimination Based on Descent. Presented at the A Paper presented to the UN Committee on the Elimination of Racial Discrimination conference in Geneva, Switzerland (August 8-12, 2002).

Diop, A. B. (198I). La société wolof. Tradition et Changement, Paris, Karthala.

Dush, C. M. K., Cohan, C. L., \& Amato, P. R. (2003). The relationship between cohabitation and marital quality and stability: Change across cohorts? Journal of Marriage and Family, 65(3), 539-549.

Ela, J. M. (1995). Fécondité, structures sociales et fonctions dynamiques de l'imaginaire en Afrique noire. La Sociologie Des Populations, Montréal, PUM/AUPELF-UREF, I89-2I5.

Finnäs, F. (1995). Entry into consensual unions and marriages among Finnish women born between 1938 and 1967. Population Studies, 49(I), 57-70.

Galster, G. C. (20I2). The mechanism (s) of neighbourhood effects: Theory, evidence, and policy implications. In Neighbourhood effects research: New perspectives (pp. 23-56). Springer.

Griffiths, P., Madise, N., Whitworth, A., \& Matthews, Z. (2004). A tale of two continents: a multilevel comparison of the determinants of child nutritional status from selected African and Indian regions. Health \& Place, I0(2), I83-199.

Hoem, J. M., Kostova, D., Jasilioniene, A., \& Mureşan, C. (2009). Traces of the Second Demographic Transition in four selected countries in Central and Eastern Europe: Union formation as a demographic manifestation. European Journal of Population/Revue Européenne de Démographie, 25(3), 239-255.

ICF International. (20I5). The DHS Program STATcompiler. Retrieved from http://www.statcompiler.com

Isiugo-Abanihe, U. C. (1994). Consequences of bridewealth changes on nuptiality patterns among the lbo of Nigeria. Nuptiality in Sub-Saharan Africa: Contemporary Anthropological and Demographic Perspectives, 74-91. 
Isiugo-Abanihe, U. C. (1998). Stability of Marital Unions and Fertility in Nlgeria. Journal of Biosocial Science, 30(I), 33-4I.

Isiugo-Abanihe, U. C. (2000). Female Age at Marriage and Proportions Marrying in Nigeria. African Population Studies, I5(2), 43-65.

Jensen, A.-M., \& Clausen, S.-E. (2003). Children and Family Dissolution in Norway The Impact of Consensual Unions. Childhood, I0(I), 65-8I.

Kaggwa, E. B., Diop, N., \& Storey, J. D. (2008). The Role of Individual and Community Normative Factors: A Multilevel Analysis of Contraceptive Use Among Women in Mali. International Family Planning Perspectives, 34(2), 79-88.

Kalmijn, M. (1998). Intermarriage and Homogamy: Causes, Patterns, Trends. Annual Review Sociology, 24, 395-42I.

Kalmijn, M. (20II). The influence of men's income and employment on marriage and cohabitation: Testing Oppenheimer's theory in Europe. European Journal of Population/Revue Européenne de Démographie, 27(3), 269-293.

Kamdem, K. (2006). Genre et fécondité au Cameroun: Etude comparative des Bamilléké et des Bëti.

Kamgno, H. K., \& Mengue, C. E. M. (20/4). Rise of Unofficial Marriages in Cameroon: Economic or Socio-Demographic Response? African International Journal of Social Science, 3(3), 5566.

Kennedy, S., \& Bumpass, L. (2008). Cohabitation and children's living arrangements: New estimates from the United States. Demographic Research, 19, 1663-1692.

Laplante, B. (20|4). Normative Groups: The Rise of the Formation of the First Union Through Cohabitation in Quebec, a Comparative Approach. Population Research and Policy Review, 33(2), 257-285.

Laplante, B., \& Fostik, A. L. (20/5). Disentangling the Quebec fertility paradox: The recent evolution of fertility within marriage and consensual union in Quebec and Ontario. Canadian Studies in Population, 42(I-2), 8I-I0I.

LeGrand, T. K., \& Younoussi, Z. (2009). Consensual Union in Burkina Faso: Trends and Determinants. Canadian Studies in Population, 36(3-4), 267-294.

Lindberg, L. D., \& Orr, M. (20II). Neighborhoodlevel influences on young men's sexual and reproductive health behaviors. American Journal of Public Health, I0I(2), 27I-274.

Locoh, T. (2002). Fertility decline and family changes in Sub-Saharan Africa. Journal of African Policy Studies, 8(2-3), 17-50.

Lyngstad, T. H. (20lI). Does community context have an important impact on divorce risk? A fixedeffects study of twenty Norwegian first-marriage cohorts. European Journal of Population/Revue Européenne de Démographie, 27(I), 57-77.

Martin, T. C. (2002). Consensual unions in Latin America: Persistence of a dual nuptiality system. Journal of Comparative Family Studies, 35-55.

McLanahan, S. (2004). Diverging destinies: How children are faring under the second demographic transition. Demography, 4I (4), 607-627.

Meekers, D. (1992). The process of marriage in African societies: A multiple indicator approach. Population and Development Review, I8(I), 6I78.

Merlo, J., Chaix, B., Ohlsson, H., Beckman, A., Johnell, K., Hjerpe, P., ... Larsen, K. (2006). A brief conceptual tutorial of multilevel analysis in social epidemiology: using measures of clustering in multilevel logistic regression to investigate contextual phenomena. Journal of Epidemiology and Community Health, 60(4), 290-297.

Musick, K., Brand, J. E., \& Davis, D. (20I2). Variation in the relationship between education and marriage: Marriage market mismatch? Journal of Marriage and Family, 74(I), 53-69.

Musick, K., \& Bumpass, L. (2012). Reexamining the Case for Marriage: Union Formation and Changes in Well-being. Journal of Marriage and Family, 74(I), I-I8.

Ntoimo, L. F. C., \& Isiugo-Abanihe, U. C. (20|4). Single and Stigmatised? Gender \& Behaviour, |2(4), 6| |4-6|37.

Ononokpono, D. N., Odimegwu, C. O., Imasiku, E. N., \& Adedini, S. A. (20I4). Does it really matter where women live? A multilevel analysis of the determinants of postnatal care in Nigeria. Maternal and Child Health Journal, I8(4), 950 959.

Osborne, C., \& McLanahan, S. (2007). Partnership instability and child well-being. Journal of Marriage and Family, 69(4), 1065-1083.

Raley, R. K., \& Sullivan, M. K. (2009). Socialcontextual influences on adolescent romantic 
involvement: The constraints of being a numerical minority. Sociological Spectrum, 30(I), 65-89.

Ringsted, M. (2004). Growing up Pregnant: Events of Kinship in Everyday Life. Africa Sociological Review, 8(1), 100-117.

Rodriguez, G., \& Elo, I. (2003). Intra-class correlation in random-effects models for binary data. The Stata Journal, 3(I), 32-46.

Rwenge, M. (2002). Culture, Genre, Comportements Sexuels et MST/sida au Cameroum.,(Provinces du Centre et de l'Ouest). Cahiers de l'IFORD, (28), 276.

Schmeer, K. K., \& Kroeger, R. A. (20I I). Union type and depressive symptoms among Mexican adults. Journal of Family Issues, 32(I2), |597-|62|. http://doi.org/|0.1 |77/01925 I3X| |4093 I0

South, S. J., \& Baumer, E. P. (2001). Community effects on the resolution of adolescent premarital pregnancy. Journal of Family Issues, 22(8), 10251043.
South, S. J., \& Crowder, K. (2010). Neighborhood poverty and nonmarital fertility: Spatial and temporal dimensions. Journal of Marriage and Family, 72(I), 89-104.

Speizer, I. S., Whittle, L., \& Carter, M. (2005). Gender relations and reproductive decision making in Honduras. International Family Planning Perspectives, $|3|-139$.

Thiriat, M.-P. (1999). Les unions libres en Afrique subsaharienne. Cahiers Québécois de Démographie, 28(I-2), 8I-II5.

UNDP. (2014). Human Development Report 2014. New York: United Nations Development Programme.

van de Kaa, D. J. (1987). Europe's Second Demographic Transition (Population Bulletin No. 42(I)). Washington DC: Population Reference Bureau. 